\title{
Shaping the User: An Academic Exercise
}

\author{
Sally Brett
}

Read through the collected papers of one person in the Manuscript Collection, Joyner Library. Then select four or five letters you think best reveal the personality of the writer. In the letters, clarify references to events or persons; put brackets in by hand if your typeuriter has nome. Longer explanations will have to be footnoted. Write an introductory essay (not exceeding two pages) in which you describe the letter writer (you can herecite other letters or journals) and provide some biographical information. You may want to "introduce" each letter with a sentence or two explaining what the letter reveals or evinces, or you may want to confine such comments to the prefatory essay.

Be imaginative. Try to select letters centering on one event or person, or letters that chronologically reveal change, development, or deepening of a feeling or situation.

Make one copy for your student editor and one for the instructor.

I first made this assignment five years ago, as part of the requirements in a course dually focused on regional women's literature and editing/writing. It is now a regular first assignment in the East Carolina University Department of English graduate course in bibliography and methods, in a history course at a western North Carolina school, in women's studies courses in Oklahoma, Tennessee, and Massachusetts, and in cultural studies courses in Mississippi and Michigan.

The assignment has much to recommend it, for it provides the kind of "starting point" that characterizes most creative and stimulating coursework. It provides an introduction to the stuff from which history texts, novels, and essays are derived. It makes texts real. It provides an illustration of the epistolary style and the techniques of analyzing that genre. It demands that the student learn some of the more esoteric and

\footnotetext{
Sally Brett is Associate Professor, Department of English,

East Carolina University in Greenville.
}

sophisticated library reference sources-something beyond Reader's Guide to Periodical Literature or Book Review Digest. It calls for some synthesizing skills and discriminating reading. It makes evident the interconnections of such humanities studies as history, literature, and cultural geography.

For the instructor, two happy benefits are paramount. She too can learn library resources that her specialized graduate training might not have promoted. I for one had not, in my study of the modern British novel, been apprised of NUCMC or state historical collections. Second, some of the best student efforts I have ever seen, in twelve years of college training, come from this assignment. One student did a masterly comparison of the letters of Civil War soldiers, one an illiterate Confederate footsoldier and the other an educated young officer from Massachusettsdiverse in background but identical in their dislike and fear of war. Another student took the minutes of a book club and extracted the unwritten code of behavior with which the turn-of-thecentury ladies enocuraged each other to venture beyond the totally private domestic world to the larger public world of civic concern and culture.

Yet, for all the challenges afforded the students assigned to work in a manuscript collection and the pedagogical rewards for their instructor, this assignment is one that many of my colleagues say they cannot make. The instructors in Oklahoma, Tennessee, Massachusetts, and other states mentioned above tried this assignement only after some urging on my part and not a little misgiving on theirs. Other instructors have flatly said that such an assignment would be impossible at their schools. Why? Because, they say, the curators of their manuscript collections, or their archivists, do not welcome students. They do not want undergraduates in their collections or archives. Still others, a minority, claim that their collections or archives do not have the kind of material that ours at East Carolina does. To answer the second objection first: the ECU collection is not the Berg, by any means. It is a decent collection by anyone's standards, but the material 
is, for the most part, that of ordinary citizens, not stellar literary or historical figures. But the ordinariness is precisely the point of the assignment. The extraordinary in the everyday is the wonderful revelation that researchers, undergraduate and professional, come to in such collections.

As for the curators and archivists who bar undergraduates from their doors, bringing such students in with an assignment like mine assures the curator that he will be in firm control of what materials are used by whom and when. Furthermore, my students are not dropped into the collection. They are introduced first with a lecture, on the collection premises, by the curator, on the proper way to find and to handle collection materials. Designated collections are shown to them, and again proper handling and note-taking are explained.

The rewards are not all those of instructor and student. The collection benefits too. Made newly aware of what constitutes "savable" materials, students carry home a respect for the letter, diary, or business records of great-grandparents, a respect which has more than once resulted in either a donation to the collection or the opening to the curator of a family archive. Bringing students in on such an assignment is a rare chance for the archivist or curator to create and to mold awareness, to form intelligent and educated collection users.

\section{REGIONAL LOCAL HISTORY GENEALOGY}

PUBLISHERS and BOOKSELLERS of reprints and originals ... Regional and County History, Genealogical source material, Colonial Americana, Revolutionary and Civil War material ... Primary emphasis on Southeastern states ... Publications of the South Carolina Historical Society and North Carolina Genealogical Society. Write for complete catalogue.

Thomas E. Smith Publisher

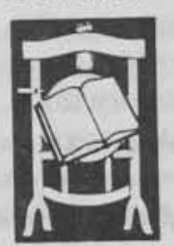

THE REPRINT COMPANY, PUBLISHERS

Post Office Box 5401

Spartanburg, S.C. 29304 